\title{
Místní lidové soudy jako fenomén doby v teorii a praxi
}

\author{
Jindřich Špergl
}

Právnická fakulta, Univerzita Karlova

Kontaktni e-mail: J.Spergl@seznam.cz

\section{The Phenomenon of Local People's Courts in the Theory and Practice}

\begin{abstract}
:
The article deals with the Local People's Courts (LPC), which were the basic element of the judicial system of Czechoslovakia between 1961 and 1970. The aim of the article is to provide a basic probe into this institute both theoretically and practically. The LPC were a specific product of the early 1960s, when the theses on the victory of socialism and the transition to the higher stage of the social development of communism were proclaimed in Czechoslovakia. The LPC became significant signs of this development, as mixed bodies of state authorities and workers. After defining the historical and ideological reasons for the LPC, including a reference to their predecessors, the Comrades Courts, the article also deals with the legal regulation of these courts. Here is outlined the way they were set up, their composition, their jurisdiction and the procedure before them. After describing the legal framework of the LPC, there follows a list of the factual deficiencies of it such as uncertainty in a number of legal questions, the participation of a laic element only in decision-making and the inequality of the offenders in the LPC system. Part of the article captures the LPC periodical evaluation in the professional press as well as the authorities of the ruling Communist Party. The theoretical part is followed by the practical part, which is a probe into the life of one particular LPC (Shipyard, national company Mělník). This provides a comparison between theory and practice. Based on authentic archive materials, it provides insight into the decision-making practice and internal mechanisms of this court. The last part of the article is devoted to the abrogation of MLS and its reasons.
\end{abstract}

\section{Keywords:}

local people's court; comrades court; offense; mixed bodies of state authorities and workers; inequality of the offenders 


\begin{abstract}
Klíčová slova:
místní lidový soud; soudružský soud; provinění; smíšený soudní orgán; nerovnost provinilců
\end{abstract}

DOI: $10.14712 / 2464689 X .2019 .10$

Místní lidové soudy (MLS) byly součástí vývoje československého soudnictví po roce 1948, tj. v době, kdy došlo k jeho zlidovění. Koncepčně se jednalo o specifický produkt socialistické soudní organizace. Ač byly soudobou literaturou prezentovány jako další prvek zlidovění soudnictví, přeci jen se od dosavadního vývoje tohoto procesu zásadně odlišovaly. Zatímco od vydání zákona o zlidovění soudnictví se toto doposud projevovalo participací laiků (soudců z lidu) na rozhodovací činnosti soudů (státních orgánů) obsazených profesionálními soudci, tj. řekněme na infiltraci státního orgánu $\mathrm{z}$ vnějšku, $\mathrm{v}$ př́ípadě MLS došlo k přenesení samotné funkce státního orgánu na nestátní společenský a plně laický orgán. Byt' je třeba $\mathrm{k}$ tehdejším oficiálně proklamovaným názorům přistupovat zdrženlivě a kriticky, je možno v souladu s dobovou literaturou označit MLS za „naprosté novum“, 1 jež se ze všech soudních institucí nejvíce blížilo představám marxisticko-leninské koncepce uspořádání společenských vztahů. ${ }^{2}$ Rovněž doba, ve které MLS působily, tj. od roku 1961 do roku 1970, je sice dobou relativně krátkou, ale pro vývoj našeho státu převratnou. V tomto ohledu je možno MLS označit i jako fenomén doby, nebot' jak počátek, tak konec jejich činnosti determinovaly klíčové dějové momenty naší historie a MLS jsou z tohoto hlediska flagrantní ukázkou toho, jak totalitní systém přizpůsoboval právní normy svým aktuálním potřebám.

Cílem př́spěvku je náhled na MLS jako na dobově ideologicky podmíněný specifický produkt vývoje společnosti, a to $\mathrm{v}$ rovině teoretické a zejména pak praktické, na podkladě rozhodovací činnosti a vnitřních mechanismů konkrétního soudu. Článek je zaměřen na projednávání provinění a trestných činů MLS a zcela vynechává agendu drobných majetkových sporů.

\title{
1. Místní lidové soudy jako fenomén doby
}

Každá změna platného práva v sobě zákonitě odráží dobovou realitu, která ji podnítila. Komunistická vláda proměnila Československo doslova v jednu velkou právní laboratoř, která ohýbala a překrucovala právní rád podle potřeb totalitního systému. To se projevilo i ve 2 . polovině 50 . let minulého století, kdy se komunistický režim navenek stabilizoval po krizi, vyvolané mimo jiné odhalením kultu osobnosti a neuspokojivými hospodářskými výsledky, př́slibem „lepších zítřkư“. Ideologickým vrcholem takového přístupu bylo přijetí nové ústavy a v ní vyhlášení teze o „vítězství socialismu v naší vlasti“ a přechodu do vyšší vývojové fáze komunismu. ${ }^{3}$

1 Toto konstatoval např. Dr. Otakar Osmančík, který ve svém článku nazvaném K problematice místních lidových soudů uvádí: „Zakotvením zásady, že místní lidové soudy jsou článkem jednotné soustavy československého socialistického soudnictví, vznikla situace, která neměla u nás, a patrně ani ve světě obdoby." Srov. OSMANČÍK, O. K problematice místních lidových soudů. Socialistická zákonnost, 1966, roč. XIV, č. 4, s. 196.

2 Srov. např. LENIN, V. I. Spisy, sv. 28. Praha: SNPL, 1955, s. 328.

3 Srov. Prohlášení k ústavnímu zákonu č. 100/1960 Sb. 
Podle tehdejšího vidění světa společnost ve fázi socialismu zrodila profil nového člověka se socialistickou morálkou, který „rozvíjí a upevňuje nový vztah k socialistickému právu. Proto je také ve své většině nejenom dobrovolně dodržují, ale i sami pečují o jejich zachovávání.“4 Jako prvořadý cíl v tomto ohledu bylo stanoveno „umožnit pracujícím v daleko širší míře přímo se podílet prostřednictvím společenských organizací na rozhodování o některých přestupcích proti zákonům“. ${ }^{5} \mathrm{Na}$ základě těchto idejí byl dne 18. 4.1957 schválen zákon č. 24/1957 Sb., o kárném stíhání rozkrádání a poškozování majetku v socialistickém vlastnictví a později byly ustavovány soudružské soudy. Impulsem pro jejich ustanovení byla směrnice politického byra ÚV KSČ z 21. 4. 1959. Jejich vznik nebyl spojen s žádnou právní normou, nebot' prováděcí pokyny k jejich ustanovování byly uvedeny v dopise ministra vnitra č.j. 140/1960 ze dne 22. 4. 1960, který vyžadoval k založení soudružského soudu předchozí souhlas OV KSČ. Soudružské soudy byly voleným orgánem s funkčním obdobím jednoho roku. Před soudružskými soudy se projednávaly př́ípady hrubého porušení pracovní kázně a veřejného pořádku, např. chuligánství, opilství, urážky, pomluvy, drobné krádeže socialistického a osobního vlastnictví. ${ }^{6}$

M. Dočkal na základě zkušeností s kárnými komisemi a soudružskými soudy konstatoval: „Ukázalo se, že dosavadní donucování státem v trestní oblasti není jedinou možnou formou práce a na druhé straně, že k výkonu soudní praxe není třeba bezpodmínečně specializovaných odborníků. Ze všech př́padů vzájemného prolínání forem činnosti na tomto úseku pak vyplývají první konkrétní obrysy způsobu splývání právních a mravních norem na cestě ke komunismu. "7

Po krátkém intermezzu zákonně nikdy neupravených soudružských soudů a po ,využití kladných zkušeností z jejich činnosti“ zcela v duchu dynamiky doby spatřily světlo světa MLS, coby smíšené orgány státu a pracujících. MLS se však nestaly jen právní kategorií, nýbrž i jakousi ideologickou kategorií dokazující přechod společnosti do vrcholné fáze vývoje - komunismu - , o čemž svědčí následující citace: „Zřízením místních lidových soudů byl učiněn v oblasti soudnictví jeden z významných kroků, naznačující směr vývoje soudních orgánů od orgánů státu v orgány budoucí komunistické samosprávy.“8

\section{Zákonná úprava MLS}

První právní normou zmiňující MLS byla Ústava ČSSR, ${ }^{9}$ která v čl. 98 odst. 2 začlenila MLS do soudní soustavy ČSSR a dále v čl. 101 proklamovala důvod jejich existence jako „další prohlubování účasti pracujících na výkonu soudnictvi““ v duchu „upevňování socialistické zákonnosti projevující se v zajišt’ování společenského pořádku a pravidel

$4 \quad$ Zvýšeni pravomoci a odpovědnosti národnich výborů a opatření $k$ dalšímu prohlubování socialistické zákonnosti: zasedání ÚV KSČ ve dnech 7.-8. 4. 1960. Praha: Ústřední výbor KSČ, 1960.

5 Tamtéž.

6 Bliže k soudružským soudům např.: PLUNDR, O. Místní lidové soudy a zkušenosti se soudružskými soudy v jiných zemích socialistického tábora. Praha: Československá společnost pro šíření politických a vědeckých znalostí, 1961.

7 DOČKAL, M. K historii soudružských soudů. In: Sborník praci Filozofické fakulty Brno. Brno, 1962 , S. 106.

8 PLUNDR, O. Organizace justice a prokuratury. Praha: Orbis, 1964, s. 85.

9 Terminologicky se „miestne ludové súdy“ ve vývoji československého práva objevily poprvé v nařízení SNR č. $33 \mathrm{Sb}$. n. SNR, kde však měly odlišný charakter, a to nejnižšího článku retribučního soudnictví na území Slovenska. 
socialistického soužití“. Současně stanovila, že MLS budou voleny v místech a na pracovištích. Rozsah pravomoci MLS, způsob, jak se zřizují, jejich volební období i zásady jejich organizace a jednání měl stanovit zákon.

Samotný zákon o MLS byl vyhlášen pod číslem 38/1961 v částce 16/1961 Sbírky zákonů Československé socialistické republiky, platnosti nabyl 28. 4. 1961, účinnosti pak 1. 7. 1961. Obsahem právní úpravy se jednalo o zákon do jisté míry specifický, nebot' šlo o kombinaci institucionální (vznik MLS jako instituce), procesní (upravující jednání před MLS) a hmotněprávní (konstrukce provinění, coby kategorie deliktu) normy.

MLS byly orgány subsidiárními, nebot' zákon jim ukládal, aby svou činnost vyvíjely v úzké spolupráci se všemi státními a společenskými organizacemi a aby samy zakročovaly jen v těch prrípadech, kdy státní orgány a společenské organizace nemohly zjednat nápravu svým vlastním výchovným působením. ${ }^{10}$

MLS mohly být zrrizovány $\mathrm{v}$ obcích nad 3000 obyvatel a na některých pracovištích, naopak jejich vznik byl přímo zakázán v ozbrojených složkách a ve státních orgánech. Jednalo se o instituci fakultativní, nebot' jejich ustanovení bylo založeno pouze na dobrovolném rozhodnutí místního národního výboru, resp. základní organizace Revolučního odborového hnutí (ROH) př́islušného závodu. O zřízení MLS rozhodoval vždy okresní národní výbor, v jehož obvodu působnosti měl být MLS ustanoven. Návrh na zřízení MLS podával místní národní výbor obce, v níž měl být MLS zřízen, resp. základní organizace ROH př́slušného závodu. Ve velkých městech mohly být MLS zřizovány pro jednotlivé městské obvody a $\mathrm{v}$ průmyslových podnicích s velkým počtem zaměstnanců i pro jednotlivé závody. V městech s většími průmyslovými podniky mohly MLS být zřizovány v podnicích i u př́slušného MNV.

Soudci místních lidových soudů byli voleni na dva roky veřejným hlasováním na shromážděních občanů na návrh místního národního výboru nebo základní organizace $\mathrm{ROH}$. Aktivní volební právo měli občané, kteří dovršili 18. rok věku, pasivní ti, kteří dovršili 21. rok věku a požívali mezi občany všeobecné vážnosti a důvěry a kteří byli ostatním občanům prríkladem v práci, ve veřejné činnosti i v osobním životě. Obdobným způsobem jako probíhala volba soudců, bylo možno soudce z jeho funkce odvolat, pokud neplnil své soudcovské povinnosti anebo ztratil-li z jiného důvodu důvěru pracujících.

Zákon o MLS svěřil, pokud jde o věcnou příslušnost do pravomoci MLS trri skupiny záležitostí, a to provinění, méně závažné trestné činy a některé věci občanskoprávní. V případě provinění to byl právě samotný zákon, který tuto deliktní kategorii zavedl. Proviněním byla zaviněná jednání uvedená v § 16-21 zákona o MLS, kterými byl porušen socialistický právní řád v takové míře, že to ohrožovalo nebo poškozovalo zájmy společnosti nebo práva a oprávněné zájmy jednotlivce, jestliže vzhledem k okolnostem př́ípadu, k osobě provinilého občana a k následkům jeho jednání nedosahovaly stupně společenské nebezpečnosti trestného činu ( $§ 15)$. Dle objektu porušení socialistického právního řádu byla zákonem rozlišována provinění proti majetku v socialistickém vlastnictví (§ 16), provinění proti majetku v osobním vlastnictví (§ 18), provinění proti zájmům socialistického hospodářství (§ 17), provinění proti socialistickému soužití (§ 19), provinění proti rodinným vztahům a zájmům zdravého vývoje mládeže (§ 20) a provinění proti pracovní kázni (§ 21).

10 Srov.: úst. zák. č. 100/1960 Sb., Ústava ČSSR, čl. 17 a zák. č. 38/1961 Sb., zákon o místních lidových soudech, $\S 2$. 
Méně závažné trestné činy, o nichž jinak rozhodovaly okresní soudy, mohly podle zákona rozhodovat MLS jen za podmínky, že jim byly postoupeny prokurátorem nebo okresním soudem. Instrukce ministra spravedlnosti k provádění zákona o MLS ze dne 31. 5. 196111 upřesnila, že postoupení trestného činu k projednání MLS mohlo být realizováno jen v př́ípadech zcela jasných po skutkové i právní stránce. Instrukce předpokládala, že postup uskuteční zpravidla prokurátor, a to již ve stadiu př́pravného ř́zení trestního, tj. vyšetřování. Okresní soud postupoval MLS trestní věc v situaci, kdy prokurátor již podal k soudu obžalobu a soudce dospěl k závěru, že věc může projednat MLS. V obou případech, tj. jak v postoupení prokurátorem, tak okresním soudem, instrukce předpokládala předchozí konzultaci s předsedou MLS. Pro provinění nebo méně závažný trestný čin mohli být před místní lidový soud postaveni pouze občané, kteří v době, kdy se dopustili činu, dosáhli věku 15 let. Činy mladistvých (od 15 do 18 let), náležejících do pravomoci MLS, mohly být těmito projednány jen tehdy, když nápravu mladistvých nemohly uskutečnit společenské organizace, zejména ROH nebo ČSM. Výjimečně mohly být MLS postupovány méně závažné trestné činy mladistvých.

Za spáchání provinění nebo méně závažného trestného činu MLS ukládaly opatření: napomenutí, veřejnou důtku, pokutu do 500 Kč, nápravné opatření srážkou z platu až do $15 \%$ na dobu nejvýše tří měsíců. Jen MLS na pracovišti mohly navíc nařídit, aby byl provinilý občan přeložen v rámci pracoviště na nižší funkci nebo na jiný pracovní úsek na dobu nejvýše 6 měsíců. MLS mohly též uložit propadnutí věci patřící provinilému občanu, pokud ji použil ke spáchání provinění nebo trestného činu, resp. ji při spáchání činu získal. MLS nemusely vůbec opatření uložit a mohly se omezit pouze na projednání věci, pokud to okolnosti případu dovolovaly. MLS mohly provinilému uložit povinnost k náhradě škody, kterou svým jednáním způsobil.

Jedním z projevů zařazení MLS do soustavy soudů byla možnost podat proti jejich rozhodnutí opravný prostředek, a to bud' odvolání, nebo stížnost pro porušení zákona.

Řízení o odvolání bylo v zákoně upraveno v $\$ 33$ a dvou paragrafech po něm následujících. Odvolání bylo jediným řádným opravným prostředkem proti rozhodnutí MLS. Tím byla založena dvojinstančnost řízení před MLS. Odvolání se podávalo ústně nebo písemně u předsedy MLS nebo jeho zástupce, a to ve lhůtě 15 dnů od vyhlášení rozhodnutí MLS. O odvolání, které mělo odkladný účinek, rozhodoval okresní soud. Aktivně legitimovány k podání odvolání byli kromě občana, jehož se rozhodnutí přímo dotýkalo, jeho zákonný zástupce, prokurátor a orgány nebo organizace, které daly podnět k projednání věci. Okresní soud rozhodoval o odvolání v tř́členném senátu. Zjistil-li okresní soud, že rozhodnutí MLS je nezákonné nebo z jiných důvodů nesprávné, zrušil je a vrátil MLS věc k novému projednání a rozhodnutí. Při novém projednávání věci byl MLS povinen řídit se pokyny obsaženými v rozhodnutí okresního soudu.

Mimořádný opravný prostředek proti pravomocnému rozhodnutí MLS, stížnost pro porušení zákona, mohl podle $\S 39$ odst. 1 podat okresní prokurátor nebo předseda okresního soudu. O takto podané stížnosti rozhodoval okresní soud. Byl-li pravomocným rozsudkem okresního soudu, kterým rozhodl o odvolání proti rozhodnutí MLS, porušen zákon, mohl stížnost pro porušení zákona podat krajský prokurátor nebo předseda krajského soudu. O takové stížnosti rozhodoval krajský soud.

11 Sbirka směrnic pro národni výbory. Praha, 1961, částka 5. 
K provedení zákona o MLS byla vydána řada podzákonných předpisů, např. instrukce ministra spravedlnosti z 31. 5. 1961, která mj. stanovila povinnost okresním soudům poskytnout MLS veškerou součinnost, či usnesení vlády ČSSR ze dne 31. 5. 1961 obsahující směrnice o úkolech národních výborů při zřizování a rozvíjení činnosti MLS, které obdobnou povinnost směrem k MLS uložily národním výborům.

\section{Faktické nedostatky v zákonné úpravě MLS}

První a zásadní nedostatek zákonné úpravy MLS byl samotný charakter této úpravy. Zákon o MLS totiž dle slov dr. Jaroslava Pastorka, předsedy trestního kolegia Nejvyššího soudu, „upravuje pouze základní otázky ustanovování, činnosti a řízení MLS“, nebot’ „politickým požadavkem bylo, aby zákon o MLS nebyl zatížen přemírou ustanovení upravujících podrobně všechny otázky řízení před místními lidovými soudy, aby se pracující, pro které je zákon především určen, mohli rychle a bez velkých nesnází seznámit se zásadami zákona“. ${ }^{12}$ Takový charakter zákona spolu s faktem, že ho měli aplikovat v prvé řadě v právu nevzdělaní lidé, vedl velmi brzo po jeho aplikaci k potřebě upřesnění a výkladu některých otázek. A tak dne 1. 3. 1963 zasedalo plénum Nejvyššího soudu za účasti předsedů krajských soudů, ministra spravedlnosti a I. náměstka generálního prokurátora s cílem přijmout směrnici k výkladu zákona o MLS. Při tomto úkolu měli účastníci k dispozici mnoho podnětů od již fungujících MLS, kterých bylo v roce 1963 na celém území ČSSR celkem 849, a dále od okresních soudů, které měly ze zákona dozor nad činností MLS. Dr. Pastorek v této souvislosti poznamenal, že ,přri řešení těchto otázek bylo nutno vycházet především ze smyslu a politického účelu zák. o MLS“. Po prríslušném projednání byly dne 1. 3. 1963 přijaty Směrnice pléna Nejvyššího soudu k výkladu zákona č. 38/1961 Sb. o místních lidových soudech. ${ }^{13}$ Tyto směrnice se podrobně zabývaly otázkami jednání MLS a např. stanovily zákaz předvádění před MLS nebo zásadu, že MLS není vázán právní kvalifikací soudem nebo prokurátorem postoupeného skutku a může i v př́ípadě, kdy skutek byl postupujícím orgánem označen jako trestný čin, rozhodnout, že se jedná o provinění. Dále bylo napřr. stanoveno, že nápravné opatření nelze přeměnit na trest odnětí svobody a v př́padě, že po uložení nápravného opatření je na provinilém vykonáván dlouhodobý trest odnětí svobody, nelze nápravné opatření vůbec vykonat. Zatímco u některých kategorií problémů směrnice zastávaly výrazně direktivní směr, u některých otázek jejich znění vyznělo spíše jako doporučení, které navíc nebylo v budoucnu akceptováno. Výstižným př́kladem je aplikace zásady zákazu reformace in peius v př́ípadě zrušení rozhodnutí MLS, toliko na podkladě podaného odvolání ve prospěch provinilého občana. Směrnice k tomu zastávala názor, že ,uložení přísnějšího opatření bude na místě, jen pokud při novém projednání věci místním lidovým soudem dojde k podstatnější změně skutkových zjištění v neprospěch provinilého občana“. Naproti tomu komentované znění zákona o MLS z roku 1964 uvádělo, že v případě zákazu reformace in peius „není překážek, aby v novém řízení byl skutek provinilce-odvolatele posouzen v otázce viny př́ísněji, i když nedojde k podstatnější změně skutkových zjištění v jeho neprospěch“. ${ }^{14}$

12 Blíže Zpráva ze zasedání pléna Nejvyššího soudu ČSSR. In: Sbirka rozhodnutí a sdělení soudů ČSSR. Praha: Ministerstvo spravedlnosti, 1963.

13 Směrnice pléna Nejvyššího soudu k výkladu zákona č. 38/1961 Sb. o místních lidových soudech z 1. března 1963. In: Sbirka rozhodnutí a sdělení soudu ČSSR. Praha: Ministerstvo spravedlnosti, 1963, č. 1.

14 Srov.: Zákon o mistních lidových soudech, komentár. Praha: Orbis, 1964, s. 299. 
I přes snahu se s nedostatky zákona vyrovnat řada problémů zůstávala. Koncepce zákona např. negarantovala rovnost provinilců ve vztahu ke spáchanému deliktu a jeho projednání bylo vlastně věcí náhody. Rozhodující bylo, zda v dané obci či závodu byl ustanoven MLS. Další viditelný problém byl v samotné konstrukci provinění a trestných činů upravených v zákoně o MLS. Jestliže někteří autoři hovoří zejména o době na počátku 50. let jako o hypertrofii trestní represe, ${ }^{15}$ situaci po vydání zákona o MLS bych označil jako deliktní hyperplazii. Jeden identický skutek mohl být posouzen bud' jako trestný čin nebo provinění, resp. kárné disciplinární provinění nebo přestupek, a to s odlišnými sankčními důsledky. Jediné kritérium pro diferenciaci deliktu byla společenská nebezpečnost činu pro společnost, což je ovšem vzhledem ke konstrukci většiny skutkových podstat deliktů kategorie značně vágní. Napřr. zákon o MLS výslovně neuváděl, které trestné činy lze pokládat za trestné činy menší společenské nebezpečnosti, nicméně dle komentáre $\mathrm{k}$ př́íslušnému zákonu se jednalo o činy s takovým stupněm nebezpečnosti pro společnost, kde intenzita ohrožení, resp. poškození trestním zákonem chráněných společenských zájmů vzhledem ke konkrétní situaci, osobě pachatele a výchovnému vlivu a síle kolektivu, umožňuje dosáhnout výchovného účelu i mimosoudním vyřízením. Proto pojem „trestný čin menší nebezpečnosti pro společnost“ nelze blíže vymezit nějakými znaky, podle nichž by bylo možno přesně označit, které trestné činy uvedené v trestním zákoně jsou trestnými činy menší nebezpečnosti pro společnost (např. trestné činy, u nichž zákon stanoví mírnější trestní sazby). ${ }^{16}$ Ad absurdum si při takové konstrukci lze představit, že i např. trestný čin loupeže podle $\S 234$ odst. 1 tr. zákoníku by např. za situace, kdyby ho spáchal doposud bezúhonný dělník, člen KSČ, z důvodů nedostatečných př́ijmů, které mu znemožňují dostát jeho vyživovací povinnosti vůči dvěma dětem, mohl být projednáván MLS a skončit, co do sankce, např. napomenutím. Toto nebezpečí si ostatně uvědomovala soudobá právní literatura a snažila se poskytnout určitý návod pro to, jak jednotlivé delikty od sebe oddělit. ${ }^{17}$

$\mathrm{V}$ případě trestných činů $\mathrm{v}$ gesci MLS byla vytvořena druhořadá kategorie trestných činů méně závažných, ${ }^{18}$ a to zejména tím, že za ně nebylo možno ukládat tresty jako takové, ale opatření v zákoně o MLS taxativně uvedená. Tím vznikla situace, že jak za trestný čin projednávaný MLS, tak za provinění, resp. kárné provinění, byly ukládány zcela identické sankce. ${ }^{19}$ Otázkou je, jaký byl reálný výsledek dělby deliktů na provinění a trestné činy, které projednávaly MLS. Odpovědí je, že prakticky žádný, což podporuje i fakt, že takové odsouzení nebylo zapisováno do rejstříků trestů stejně jako provinění. ${ }^{20}$ Pokud shora citovaný komentár̆ k zákonu o MLS navíc mluví o trestných činech projednávaných MLS jako o kategorii deliktů, kde lze dosáhnout výchovného účelu i mimosoudním vyřízením, je nasnadě otázka, co se rozumí oním mimosoudním vyřízením, nebot' soudobá

15 Např. ŠÁMAL, P. a kol. Trestni právo hmotné. 8 vyd. Praha: Wolters Kluwer ČR, 2016, s. 39.

16 Srov. Zákon o mistních lidových soudech, komentár, s. 53-54.

17 TOLAR, J. - GUSTAV, P. - MICHAL, L. Místní lidové soudy. Praha: Československá akademie věd, 1965 , S. $55-65$.

18 Dle $\S 26$ tr. zák. a $§ 163$ odst. 3, $§ 174$ odst. 2 tr. ř. méně závažným trestným činem je čin menšího stupně nebezpečnosti pro společnost.

19 Srov. $§ 5$ a 20 odst. 4 zák. č. 60/1961 Sb., o úkolech národních výborů při zajišt’ování socialistických pořádků, ve spojení s § 25 zákona č. 38/1961 Sb., o místních lidových soudech.

20 Srov. $§ 2$ odst. 2), odst. 3) vyhlášky ministra spravedlnosti a generálního prokurátora o rejstř́ku trestů č. $151 / 1961 \mathrm{Sb}$. 
právní úprava jinak než soudně projednat trestné činy nedovolovala, až na případy, kdy trestní stíhání zastavoval sám prokurátor, ale toliko za situace, kdy objektivní okolnosti případu trestní stíhání neumožňovaly. ${ }^{21} \mathrm{Na}$ základě shora uvedených skutečností by tedy ono „mimosoudni'“ vyřízení bylo vlastně vyř́izení MLS, které komentář de facto nepovažoval za soudní orgán i přesto, že MLS byly jako soudní orgány ústavně zakotveny.

K první a zároveň poslední novelizaci zákona o MLS došlo dne 17. 6. 1965, kdy byl přijat zák. č. 58/1965 Sb., kterým se s účinností od 1. 8. 1965 upravoval postih provinění a přestupků osob opětovně se dopouštějících výtržnictví, násilností a př́živnictví. Tímto zákonem bylo stanoveno, že provinění proti socialistickému soužití, proti pracovní kázni a přestupky proti socialistickému soužití budou moci projednávat okresní soudy s možností uložení nepodmíněného trestu odnětí svobody až na jeden rok, za předpokladu, že se jich dopustí osoba, která byla v posledním roce před jejich spácháním postižena pro některé z uvedených provinění nebo přestupek anebo v posledních třech letech pro některý z trestných činů obdobné povahy odsouzena nebo z výkonu trestu propuštěna a u níž celkové zhodnocení způsobu jejího dosavadního života ukazuje, že od postihu před místním lidovým soudem nebo národním výborem nelze očekávat její nápravu. ${ }^{22}$

I když to nikdo oficiálně nepřiznal, přijetím tohoto zákona byl konkludentně potvrzen fakt, že přerod občanů v nový typ socialistického člověka, dobrovolně se vyvarujícího páchání deliktní činnosti, se nekoná, a že dosavadní koncepce MLS v oblasti prevence kriminality selhala.

\section{Soudobé hodnocení instituce MLS}

Pro celé období komunistické vlády v Československu je charakteristický mnohdy zásadní rozpor mezi oficiálně prezentovaným hodnocením reality a realitou samou. Č́ástečnou výhodou pro hodnocení soudobé právní literatury je fakt, že MLS spatřily světlo světa v době, kdy docházelo k postupnému uvolnění napětí ve společnosti a kdy jistá míra, byt' i nepopulárních a kritických názorů a postřehů, byla z různých důvodů režimem tolerována.

Se zajímavou iniciativou přišla v roce 1965 redakce časopisu Socialistická zákonnost v souvislosti s př́ípravou XIII. sjezdu KSČ, který měl mj. hodnotit vývoj společnosti od sjezdu předcházejícího. Mezi témata sjezdu mělo patřit i hodnocení vývoje socialistického státu a práva. V této souvislosti se redakční rada časopisu rozhodla uspořádat předsjezdovou diskuzi k otázkám ochrany veřejného pořádku. Čtenáře vybídla ke sdělování osobních zkušeností a názorů mj. k činnosti MLS, zároveň však zdůraznila, že diskuse nemá mít oficiální charakter. Jako úvodní př́íspěvek byl uveřejněn článek dr. Zdeňka Kratochvíla, náměstka ministra spravedlnosti, s názvem Účast veřejnosti při převýchově rušitelů socialistického pořádku. Na nabídku diskuze pak zareagovala řada autorů svými př́spěvky, z nichž některé byly vůči MLS mimořádně kritické. ${ }^{23}$

Otázkou úspěšnosti projektu MLS se zabývala i právní komise při ÚV KSČ na své 19. schůzi konané dne 4. 2. 1966. Podkladem pro jednání byla zpráva s názvem „MLS, společenští obhájci, společenští žalobci a záruky společenských organizací“, která obsahovala

21 Srov. § 177 odst. 1, odst. 2 zákona č. 141/1961 Sb., trestní řád.

22 Blíže: BALÁŠ, O. Společenská a právní problematika zákona č. 58/1965 Sb. Socialistická zákonnost, 1968, roč. XVI, č. 1, s. 71-76.

23 Srov. např. OSMANČÍK, c. d., s. 193-196. 
výsledky I. etapy výzkumu Právnického ústavu ministerstva spravedlnosti, jenž se zabýval účinností právních předpisů a dalších opatření, provedených $\mathrm{k}$ zabezpečení realizace usnesení ÚV KSČ z 8. 12. 1960. Úkolem výzkumu bylo shromáždit a zhodnotit poznatky potřebné ke správnému posouzení ústřední otázky, zda a jak se osvědčily nové právní instituty, mj. rozhodování o proviněních před MLS a v komisích NV. Uvedená zpráva ve svých závěrech mj. konstatovala, že ,,poznatky o výsledcích práce MLS, zjištěné výzkumem neopravňují k závěrům o nesprávnosti nebo o předčasnosti právní úpravy“. Podle zjištění ve zprávě obsažených je účinnost MLS ve značném rozsahu snižována tím, že v jejich působení stále více nabývají převahy rysy působení a práce státních orgánů na úkor rysů společenského působení. Účinnost působení MLS je brzděna značnými rozdíly, které jsou v praxi mezi MLS a komisemi NV rozhodujícími o proviněních, mezi MLS na závodech a v místech, mezi českými kraji a Slovenskem, nebot' požadavek řízení a sjednocování praxe MLS a komisí NV není plněn. Zpráva za hlavní příčinu tohoto stavu označila nedostatečnou péči o MLS ze strany státních a společenských orgánů.

Na základě projednání výše uvedené zprávy přijala právní komise usnesení, ve kterém tuto zprávu vzala ,jako základ pro další zpracovávání otázek vývoje MLS“. Komise dále konstatovala, že „tendence, směřující k podceňování vývojových možností MLS a zčásti ke snahám o postupné omezení či likvidaci MLS jsou v rozporu nejenom s faktem ústavního postavení těchto soudů, ale i s výsledky analýzy dosavadních zkušeností, nejsou podloženy reálným rozborem stavu a vývojových potřeb a je třeba proti nim stavět snahu o pozitivní řešení, o hledání cest a reálných možností dalšího rozvoje MLS. Přitom je potřebí přihlížet zejména $\mathrm{k}$ těmto skutečnostem:

1. jedním ze základních negativních faktorů byly zkušenosti s projednáváním prrípadů recidivistů, kde se nejvýrazněji projevovaly momenty nedostatečnosti či bezmocnosti MLS, tato problematika je však řešena zákonem č. 58/65 Sb.

2. druhým podstatným negativním faktorem je skutečnost, že o práci MLS soustavněji nikdo v okresech a krajích nepečoval, nedocházelo k účinnému řízení jejich činnosti i rozvoje, ke koordinaci s činností komisí NV pro veřejný pořádek atd. na potřebné kvalitativní úrovni, právní komise proto doporučuje souhlasit s předloženým návrhem $\mathrm{v}$ části, kde je navrhováno zřizovat stálé pracovní komise pro otázky MLS, s tím, že těžiště práce tu má být v okresech s vazbou na kraje, celostátní komisi podobného druhu se nejeví účelné zřizovat.

3. řadu praktických potíží - např. možnost předvedení, dělba práce mezi MLS a komisemi NV (podle určitých kategorií projednávaných přestupků a provinění), potíže při projednávání trestných činů menší společenské nebezpečnosti, jež jsou MLS postupovány orgány bezpečnosti a prokuratury apod. - lze úspěšně řešit na základě platné právní úpravy, jestliže bude zaujata jasná linie v těchto otázkách, PK doporučuje, aby tyto otázky byly řešeny vydáním př́slušných směrnic pro linii $\mathrm{MV}$, prokuratury i MS a soudů.

Některé otázky dalšího vývoje MLS (otázka nerovnosti občanů v místech, kde je nebo není MLS, otázka správního řízení apod.) musí být nadále rozpracovány v komplexní souvislosti s problematikou ochrany veřejného pořádku.“

Právní komise na závěr svého jednání přijala doporučení, ve kterém instruovala své jednotlivé členy mj., aby ,prostřednictvím oddělení KV KSČ byly stranicky až do okresů sledovány a podpořeny otázky práce MLS (...) zejména i stranická péče o zřizování a práci 
komisí pro činnost MLS v okresech a krajích (...) publikovat v Rudém právu článek k problematice MLS v souladu s dnešním jednáním právní komise (...) projednat na základě závěrů právní komise problematiku MLS v ústavně-právním výboru NS.“24

\section{Rozhodovací činnost MLS při n. p. České loděnice Praha, závod Mělník}

Zhodnocení faktické činnosti všech na území ČSSR existujících MLS není možné. Překážkou není ani tak množství těchto soudů, nýbrž torzovitost dochovaného archivního materiálu, resp. v řadě případů jeho úplná absence. ${ }^{25}$ Osudy, které potkaly spisový materiál MLS, byly rozdílné. Po faktickém ukončení činnosti MLS měl být kompletní spisový materiál těchto soudů předán okresním soudům, kde byl ponechán svému osudu, který v mnoha prrípadech vyvrcholil skartačním řízením. Značná část spisového materiálu MLS tak byla zcela skartována, resp. došlo k jeho výběrové selekci př́íslušnými okresními archivy. Do značné míry unikátní je v tomto směru archivní materiál MLS při n. p. České loděnice Praha, závod Mělník. Kompletní spisový materiál, tj. včetně správních spisů soudu, tohoto MLS byl předán Okresnímu soudu v Mělníku dne 24. 8. 1972 a od té doby s ním nebylo, alespoň co do obsahu, nikterak manipulováno. Tato skutečnost vyplývá z nálezového stavu, kdy celistvý obal všech tiskovin soudu byl opatřen dvěma neporušenými pečetěmi závodu České loděnice a samotný obsah vč. dvou razítek odpovídal předávacímu protokolu. Příslušné pečetě byly sejmuty až v okamžiku nalezení tohoto materiálu dne 16. 12. $2017 \mathrm{v}$ archivu Okresního soudu v Mělníku, tj. bezmála půl století od jeho uložení. Z těchto důvodů jsem si pro zhodnocení praxe MLS vybral právě tento soud.

MLS o své činnosti podával Okresnímu soudu v Mělníku pololetní zprávy, ${ }^{26}$ a právě z obsahu těchto zpráv je možno konstatovat, že o ustavení MLS při n. p. České loděnice Praha, závod Mělník (ČLM) rozhodl závodní výbor ROH na své schůzi dne 17. 7. 1962, kdy zároveň připravil návrh soudců. Tento návrh předložil k odsouhlasení zaměstnancům závodu a následně provedl schválení kandidátů. Takto vybraní soudci, v celkovém počtu 8 (včetně předsedy a místopředsedy), složili předepsaný slib dne 19.10. 1962 do rukou předsedy MěNV v Mělníku. Př́slušné dekrety opravňující je k činnosti soudce byly soudcům předány následujícího dne. Předseda MLS absolvoval školení u Okresního soudu v Mělníku a takto proškolený následně proškolil soudce na závodě.

Zajímavé je, že ve všech zprávách o činnosti MLS se jejich pisatel zásadně mýlil, a to $\mathrm{v}$ informaci o konci 1 . volebního období MLS, které podle něj mělo skončit dnem 17. 7. 1964. Př́ jeho stanovení totiž vycházel z data ustavení MLS (schůze závodního výboru ROH, na kterém bylo rozhodnuto o ustavení MLS). Podle $\S 9$ odst. 1 věta prvá

24 NA, Fond 10/1, sv. 5, a.j. 19, Zápis z 19. schůze právní komise při ÚV KSČ konané dne 4. 2. 1966.

25 V 1. pol. roku 1965 bylo na území ČSSR celkem 1016 MLS, z toho 557 v závodech a 459 v místech. Údaj převzat z př́lohy zprávy s názvem „MLS, společenští obhájci, společenští žalobci a záruky společenských organizací".

26 Za účelem jednotného zpracování zpráv o činnosti MLS zaslal předseda Okresního soudu v Mělníku dne 29. 12. 1962 teze pro vypracování těchto zpráv. Obsahem zpráv, dle zmíněných tezí, měly být ,informace o funkčním období MLS, činnost (rozhodovací, jiná), složení MLS (práce soudců, účast na zasedání a školení), počet napadlých a projednaných případů, z toho provinění (§ 16-24) a trestných činů, jaké tresty uloženy, kolik věcí postoupeno jiným orgánům, kolik zastaveno, zproštěno, nevyřízeno, v kolika věcech podáno odvolání a jak bylo toto vyřízeno (potvrzeno, zamítnuto, věc vrácena), forma projednávání př́padů, účast občanů, besedy po vynesení rozsudku, spolupráce s jinými orgány, klady a zápory a návrhy na opatření". 
zákona o MLS byli soudci MLS voleni na 2 roky. Jejich dvouleté funkční období se však počítalo až od okamžiku složení slibu. V případě soudců MLS při ČLM tito složili předepsaný slib do rukou předsedy MěNV dne 19. 10. 1962. Před složením slibu nemohl soudce MLS svou funkci vykonávat, nebot' do té doby nebyl nikterak zavázán plnit povinnosti soudce MLS uvedené v § 5 zákona o MLS. První volební období takto složeného MLS tedy neskončilo de iure dnem 17. 7. 1964, ale až 19. 10. 1964. Co je na celé věci zarážející, je fakt, že všechny tyto zprávy byly předávány Okresnímu soudu v Mělníku a toto flagrantní pochybení nikdo neodhalil. Zpráva o činnosti MLS ze dne 14. 7. 1966 dokonce konstatovala, že „MLS při n. p. České loděnice Praha, závod Mělník, byl ustaven dne 17. 7. 1962 a předepsaný slib lidových soudců byl složen dne 19. 10. 1962. Platnost oprávnění k výkonu soudcovské činnosti vydaného MNV v Mělníku, skončila prvnímu volebnímu období dnem 17. 7. 1964. Pro druhé volební období MLS závodu byl složen předepsaný slib soudců ku dni 15. 2. 1965 s kterýmžto datem zahájil MLS svoji činnost.“ Tato zpráva nejenže chybu zopakovala, ale vnímavého čtenáře na ni i upozornila, nebot' zatímco první volební období soudců MLS bylo dle této zprávy zahájeno již okamžikem ustanovení MLS, pro počátek druhého volebního období byl zvolen až okamžik složení předepsaného slibu soudců. Ani fakt, že tyto informace byly ve zprávě uvedeny ve dvou prímo po sobě jdoucích větách, nepřiměl nikoho k zamyšlení nad touto diskrepancí.

První volební období tohoto MLS tedy skončilo 17. 7. 1964 a pro druhé volební období vykonali soudci slib dne 15. 2. 1965 a tímto dnem byla zahájena další činnost MLS. Druhé volební období započal MLS radikální proměnou. Z původního osmičlenného složení MLS zůstali pouze dva členové, přičemž dosavadní předseda ani místopředseda ve funkci nepokračovali ani jako řadoví soudci. Zpráva o činnosti MLS ze dne 14. 7. 1966 v celém svém kontextu odhalovala fakt, že o funkci soudců MLS nebyl mezi zaměstnanci př́lišný zájem a že ti, kteří se nakonec funkce ujali, neprojevovali př́lišnou aktivitu. Jak jinak si vysvětlit skutečnost, že z původního 8členného kolegia soudců MLS v dalším volebním období pokračovali pouze dva a dále fakt, že tato úplně první zpráva o činnosti MLS v novém volebním období, tj. na samém počátku činnosti MLS v novém složení, obsahuje znepokojující informaci o tom, že „se nepodařilo do soustavné aktivní práce zapojit trvale všechny členy MLS“ a že by taková situace mohla být do budoucna řešena ,pečlivějším výběrem členů již při samém ustavení nového MLS“. Znamená to tedy, že výběr soudců pro druhé volební období nebyl dostatečně pečlivý?

Tento závěr podporuje i skutečnost, že za v roce 1965 odešedšího místopředsedu MLS nebyla nalezena náhrada. V tomto kontextu nelze přehlédnout ani časovou souvislost za jaké byl MLS pro 2. volební období ustaven. I když zpráva o činnosti MLS ze dne 24. 2. 1964 upozorňovala na blížící se konec volebního období soudců, nota bene ho chybně posouvala již na červenec, a v této souvislosti zmiňovala nutnost ,již nyní se zaměřit na výběr nových členů k jejich včasnému uvedení do funkce“, ke vzniku funkce soudců MLS došlo až 15. 2. 1965, tj. bezmála 4 měsíce po skončení volebního období. Po takto relativně dlouhé období nebyl MLS schopen vyvíjet jakoukoliv činnost.

Pokud jde o vlastní rozhodovací činnost soudu, tak první případ projednal MLS dne 28. 11. 1961, poslední pak 3. 1. 1968. Od roku 1962 do roku 1968 bylo v rámci činnosti MLS projednáno celkem 29 případů týkajících se 37 osob. Ve 12 prrípadech se jednalo o provinění proti majetku v socialistickém vlastnictví (§ 16), v 6 prrípadech o provinění proti majetku v osobním vlastnictví (§ 18), v 5 případech o provinění proti socialistickému 
soužití (§ 19), ve 3 př́padech o provinění proti pracovní kázni (§ 21). Celkem 5krát MLS projednával trestný čin, a to poškození majetku v socialistickém vlastnictví, ve dvou případech rozkrádání majetku v socialistickém vlastnictví, úmyslné ublížení na zdraví a trestný čin poškozování a ohrožování provozu obecně prospěšného zařízení. Ve 2 př́ípadech provinění MLS podezřelé osoby obvinění zprostil, v 1 prrípadě věc postoupil místně příslušnému MLS a v 1 případě ZV ROH k projednání. V rámci uložených opatření MLS uložil celkem 14 veřejných důtek s uveřejněním, vyslovil celkem 5 napomenutí, 6krát uložil peněžní pokutu (v rozmezí od 100 do $500 \mathrm{Kč}$ ) a v jednom případě snížil provinilci plat o $10 \%$ na 3 měsíce. Za celou dobu činnosti MLS bylo proti jeho rozhodnutí podáno 1 odvolání a 1 stížnost pro porušení zákona.

Projednávání provinění na pracovišti probíhalo v několika fázích. Prvotní bylo oznámení o spáchání provinění, které přicházelo bud' ze závodu samotného, nejčastěji od závodní stráže, výjimkou nebyla ani udání anonymní, ${ }^{27}$ anebo z vně závodu od příslušného orgánu VB nebo od prŕíslušného prokurátora, resp. okresního nebo vyššího soudu. Tyto podněty 28 však z počátku fakticky nepřicházely přímo MLS, ale ZV ROH. ${ }^{29}$ Tento na svém zasedání celou věc nejprve projednal a podle výsledku projednávání sám ve věci rozhodl ${ }^{30}$ nebo předal Oddělení zvláštních úkolů (OZƯ) závodu s instrukcí o postoupení MLS. Zvláště u delikventů kádrů, jak osobně nazývám ty, kteří byli až doposud zcela bezúhonní s příkladnou pracovní morálkou a kteří hlavně byli členy KSČ s kladným vztahem k lidově demokratickému zřízení, ${ }^{31}$ byl případ nejdříve projednáván v užší pracovní skupině, kde po rozebrání celé kauzy a „promluvení do duše“ delikventa byl tento vyzván k přijetí závazků o zdržení se jakékoliv deliktní činnosti v budoucnu. Zároveň mu byla stanovena zkušební doba (nejčastěji dvou let), kdy delikvent bude kolektivem, a zvláště vybranými pracovníky, sledován a tito budou na něj pozitivně, za účelem jeho převýchovy, působit a v př́ípadě spáchání dalšího prohřešku mu půjde předchozí jednání k tíži. Celá věc pak byla v závodě medializována vůči ostatním pracujícím na tzv. „desítiminutovce“. Za těchto okolností věc nebyla postoupena MLS. V podstatě se jednalo o obdobu institutu podmíněného zastavení trestního stíhání. Takovýto postup byl však protizákonný, protože všechna postoupení konkrétní věci z vnějšku měla směřovat přímo k MLS, tak byla i koncipována,

27 Např. anonymní udání adresované Ředitelství Českých loděnic v Praze informující o rozkrádání majetku v závodě konkrétní osobou, obsahující takové podrobnosti případu, že jej musela psát osoba prŕmo ze závodu. Nutno podotknout, že skutečnosti v udání popsané byly pravdivé a na jeho základě byl provinilec MLS uznán vinným trestným činem rozkrádání majetku v socialistickém vlastnictví. Viz spisový materiál MLS č. M3/64.

28 Zákon připouštěl i možnost, aby sám MLS na základě vlastních informací řízení zahájil.

29 I když faktickým adresátem oznámení, pro které měly orgány SNB vytvořeny vlastní vzor č. MV č. skl. 543, byl MLS, ten ho i formálně přebíral, viz např. oznámení o provinění ze dne 13. 4. 1964 čj.: VB 10063/30-64 ve spisu MLS evidovaného pod číslem M2 64.

30 Např. záznam z pohovoru provedeného dne 11. 6. 1964 mezi zástupci ZV ROH a určitou osobou jednoznačně prokazuje tuto praxi, nebot' se v něm uvádí, že pohovor je svolán: ,na základě oznámení OO VB v Mělníku o provinění našeho zaměstnance“, tedy ne na základě postoupení věci MLS k projednání, a dále „,vzhledem k tomu, že se jedná o dobrého zaměstnance, který neměl dosud žádný přestupek, máme za to, že tento pohovor je dostačující a není důležité projednat príípad dne (převzato doslova, pozn. autor) zák. č. 38/61 Sb. u MLS.“

31 Součástí každého spisu bylo kádrové hodnocení delikventa, kde jako hlavní kritéria byla: členství v KSČ, popřípadě jiných organizacích (SČSP, ROH), vztah k lidově demokratickému zřizení, pracovní výsledky, začlenění do kolektivu. Toto hodnocení se pak výrazně projevilo v odůvodnění jednotlivých rozhodnutí. 
tedy jako „postoupení věci k projednání MLS“. Žádný mezičlánek mezi postupujícím orgánem a MLS existovat neměl. Ostatně i Instrukce ministra vnitra o úkolech Veřejné bezpečnosti při provádění zákona o místních lidových soudech, rozkaz ministra vnitra z 1. 6. 1961 č. 10/1961, jasně instruovala orgány VB, aby v případě, kdy by mělo provinění pro svoji menší závažnost projednáno jiným orgánem (nap̌r. ZV ROH, pozn. autora), měl toto orgán VB nejprve projednat s předsedou MLS. Jinými slovy byl to MLS, který měl primárně rozhodovat o projednání věci ZV ROH a nikoliv naopak. Později, přesněji od června 1964, se zavedl systém, kdy MLS oznámení od VB automaticky předkládala ZV ROH k ,projednání a posouzení způsobu vyřízení oznámení“, kdy konkrétní případ byl projednán na schůzi ZV ROH, a i když výsledek projednání oficiálně zněl jako „doporučení", ve všech takových prrípadech byl brán MLS jako závazný. ${ }^{32}$

V rámci závodu zjištěných deliktů to bylo právě OZÚ, které připravovalo spisový materiál k postoupení MLS. Za tímto účelem vyslýchalo jak provinilého, tak př́padné svědky a shromažd'ovalo další důkazy. V této souvislosti je třeba upozornit na zajímavou praxi OZÚ při ČLM, kdy v př́padě zjištění spáchání provinění v závodě usnesením ,podle $§ 164$ tr. řádu zahajovalo vyšetřování a současně podle $\S 165$ odst. 1 tr. řádu stíhalo“33 konkrétní osoby, coby provinilé z přestupku podle $\S 16$ odst. 1 zákona 38/61 Sb. ${ }^{34}$ Samotný zákon o MLS postup před podáním návrhu na projednání provinění neupravoval, pouze v $\S 24$ odst. 2 konstatoval, že návrhy na projednání věci mají být řádně doloženy potřebnými doklady, popř́ípadě mají být i uvedeni svědkové, kteří mohou osvědčit skutečnosti v návrzích uvedené. Komentované znění zákona o MLS připustilo, že zákon má mezery i tam, kde by byla výslovná úprava na místě a je proto někdy potřeba použít jiných právních předpisů, nicméně v př́padě trestního řádu by je bylo možno analogicky využít pouze v ř́zení o opravných prostředcích podaných proti rozhodnutím MLS, ve vlastním řízení před MLS je použít nelze. ${ }^{35}$ Otázkou je, zdali činnost OZÚ je možno považovat za činnost MLS, nebot' tato vlastní činnosti MLS předcházela, nebyla zákonem vůbec upravena a MLS neměl vůči OZÚ žádných oprávnění. I tak by bylo použití ustanovení tr. řádu nepř́ípustné, nebot' dle tehdy účinného znění trestního řádu vyšetřování zahajoval vyšetřovací orgán usnesením, jehož opis do 48 hodin doručil prokurátorovi. Vyšetřovacím orgánem se pak taxativně rozuměli vyšetřovatelé prokuratury a vyšetřovatelé ministerstva vnitra, resp. velitelé v ozbrojených silách. ${ }^{36}$ Nota bene pokud by pracovník OZÚ vycházel důsledně z účinného znění trestního řádu, musel by zároveň osobu obviněného poučit o možnosti proti takovému usnesení podat stížnost a taková možnost by musela být zachována. ${ }^{37}$ Dále by musela následovat fáze skončení vyšetřování, kde by obviněnému musely býti předloženy vyšetřovací spisy k prostudování a zároveň by měl být poučen o svém právu navrhnouti doplnění vyšetřování, o čemž by musel být sepsán patřičný protokol, což se

32 Srov. Předložení věci MLS ZV ROH ze dne 9. 6. 1964, výpis ze schůze ZV ROH ze dne 11. 6. 1964 a př́ípis MLS Okresní prokuratuře v Mělníku ze dne 24. 6. 1964 ve spisu MLS M4/64.

33 Zde se OZÚ inspirovalo tiskopisem MV č. skl. 523, usnesení o zahájení vyšetřování.

34 Usnesení OZÚ ČLM ze dne 7. listopadu 1963.

35 Srov. Zákon o mistních lidových soudech, komentár, s. 13-14.

36 Srov. $§ 159$ odst. 1, odst. 2 a $§ 164$ zákona 141/1961 Sb., trestní řád, ve znění účinném do 31. 7. 1965.

37 Srov. $\$ 171$ odst. 1 zákona 141/1961 Sb., trestní řád, ve znění účinném do 31. 7. 1965, podle kterého: „Proti každému usnesení vyšetřovacího orgánu může obviněný podat stížnost. Nevyhoví-li vyšetřovací orgán stížnosti sám, předloží ji neprodleně prokurátorovi.“ 
nestalo. ${ }^{38}$ Použití ustanovení o zahájení vyšetřování, resp. trestního stíhání orgánem OZÚ v případě projednání provinění je tedy nutno vnímat jako nepřípustný exces, který navíc výrazně krátil práva obviněného. Ne př́iliš št’astný byl i fakt, že referent OZÚ v ČLM byl zároveň soudcem MLS a dokonce v př́padech, které zpracovával, vystupoval později i jako předseda senátu MLS.

Pokud šlo o postoupení trestného činu k projednání MLS přímo prokurátorem ve smyslu ust. $\S 174$ odst. 2 tr. řádu byla praxe MLS obdobná. Ač př́íslušná dikce trestního řádu i zákona o MLS ${ }^{39}$ zněla jasně, a to, že konkrétní trestní věc je prokurátorem postupována př́imo MLS k projednání, přesto byla nejdřive projednávaná ZV ROH a následně postoupena k vyřízení MLS. Tato praxe měla za následek neúměrné prodlužování projednávání trestních kauz u MLS, ${ }^{40}$ nebot' např. již 6. 4 . 1964 Okresní prokuratura Nymburk postupuje MLS skutkově jednoduchou trestní věc, ${ }^{41}$ ale MLS rozhoduje až 22. 6. 1964, nebot' před tím dne 28. 5 . 1964 byla věc předběžně projednána ZV ROH, který ji postupuje k vyřízení MLS. ${ }^{42}$

I v případě postoupení věci k vyřízení jinému místně příslušnému MLS nebyl požadavek rychlého vyřízení věci naplňován. To se stalo např. v př́ipadě provinilce Š. V., 23letého dělníka svářeče, který měl dne 26. 6. 1963 způsobit zranění zaměstnankyni V. Š. ze závodu ČLM tím, že ji udeřil do břicha, a tato byla v jiném stavu, tak, že musela vyhledat lékařskou pomoc a byla 14 dní práce neschopna. Celý případ byl dne 18. 9. 1963 MLS postoupen OO VB Mělník. Vzhledem k tomu, že provinilec V. Š. rozvázal pracovní poměr v ČLM ke dni 5. 9. 1963, byl podle údajů z rejstř́ku MLS jeho spis sp. zn. M 3/63 postoupen dne 18. 9. 1963 MLS při MěNV v Mělníku jako MLS příslušnému podle místa pobytu provinilce. Bohužel kompletní spisový materiál MLS Mělník nebyl nalezen, a tak o pokračování prípadu se dozvídáme pouze z dochované kopie rejstříku MLS Mělník. Záznam v tomto rejstříku je však dosti matoucí, nebot' shora uvedená kauza byla podle něho postoupena tomuto soudu až dne 23. 1. 1964 Okresním soudem v Mělníku a zaevidována pod sp. zn. M 4/64. Bez příslušného spisu se můžeme jen dohadovat, jak se MLS ČLM napřímo postoupený spis MLS Mělník dostal oklikou k Okresnímu soudu v Mělníku a zpět k MLS Mělník. Jedinou legální možností, jak k tomuto postupu mohlo dojít je, že MLS Mělník postoupený spis dále postoupil podle $\S 32$ odst. 3 zákona o MLS okresnímu prokurátorovi se závěrem, že čin V. Š. je trestným činem. Prokurátor se s tímto názorem ztotožnil a podal k Okresnímu soudu obžalobu. Ten ji v rámci předběžného projednání projednal a rozhodl podle $\S 188$ odst. 1 písm. b) nebo c) tr. řádu postoupit věc MLS Mělník s tím, že se jedná bud' o trestný čin menší nebezpečnosti pro společnost, resp. provinění. Z dochované kopie záznamu v rejstř́iku MLS Mělník nelze bohužel zjistit, jak byl delikt V. Š . vlastně právně kvalifikován. Celý případ skončil tím, že provinilému V. Š. bylo dne 14. 2. 1964 uloženo

\footnotetext{
38 Srov. § 169 odst. 1 zákona 141/1961 Sb., trestní řád, ve znění účinném do 31. 7. 1965.

39 Srov. § 174 odst. 2 zákona 141/1961 Sb., trestní řád, ve znění účinném do 31. 7.1965 a $§ 13$ odst. 1 zákona o MLS.

$40 \quad$ Viz urgence Okresního prokurátora v Nymburce ze dne 2. 6. 1964, sp. zn. M 1/64.

41 Trestný čin poškození majetku v socialistickém vlastnictví, spočívající v poškození sociálního zařízení ŽST Lysá nad Labem se škodou 696 Kč. Oba provinilci byli chyceni krátce po činu, ke kterému se doznali a jejich vinu potvrdili i svědci.

42 Viz spisový materiál MLS ČLM sp. zn. m 1/64, zvláště přípis MLS ze dne 8. 6. 1964 Okresní prokuratuře v Nymburku.
} 
MLS Mělník napomenutí. Z povahy této sankce by se dalo usuzovat, že delikt provinilého V. Š. byl projednán jako provinění.

O tom, jak vypadalo samotné projednání jednotlivých kauz před MLS nelze ze spisového materiálu do roku 1965 učinit žádný závěr, nebot' spisy z let 1962-1964 neobsahují žádné protokoly o jednání. ${ }^{43}$ Toliko na základě dochovaného spisového materiálu z let 1962-1964 by mohl být učiněn závěr, že MLS rozhodovací činnost uskutečňoval jen na základě podkladů získaných mimo soud samotný, osoby obviněné a případné svědky nevyslýchal a rozhodnutí činil od stolu, bez nařízení vlastního jednání, a to zcela ve shodě se stanoviskem ZV ROH. Pokud by MLS jednání skutečně konal, jeví se jako nelogické, proč by protokol o takovém jednání nevyhotovil a do spisu nezaložil, když ostatně podle $\S 29$ odst. 4 zákona o MLS bylo pořizení protokolu o každém jednání povinností MLS. Takovouto praxi by však bylo třeba označit za naprosto odporující samotné koncepci MLS, kdy právě veřejné projednání a po něm následující diskuse měla být jedním z pilírư koncepce MLS. Nutno podotknout, že zpráva o činnosti soudu za rok 1962 neobsahuje žádné informace o veřejně konaných jednáních MLS. Na konci roku 1962 pak předseda Okresního soudu v Mělníku vydává ,téze pro vypracování zprávy o činnosti MLS“, kdy v bodě III. požaduje informaci o formě projednávání př́padů, účasti občanů a konání besed po vynesení rozsudku. Následná zpráva o činnosti MLS za rok 1963 již obsahuje informaci o tom, že „,všechna projednávání uvedených př́ípadů (za rok 1963, pozn. autor) byla uskutečněna za účasti zaměstnanců závodů a rovněž tak po každém projednání a vynesení rozsudku bylo přikročeno $\mathrm{k}$ besedě o př́ípadu. Ve všech př́ípadech vyplynul z besedy souhlas vyneseným rozsudkem. " 44 Č́stečně matoucí je i fakt, že od roku 1965 se již ve spisech protokol o jednání nachází. V těchto protokolech je vedle složení senátu, osob obviněných a svědků zachycen celý průběh jednání a dokazování, a to včetně takových podrobností, jako je údaj o počtu př́itomných osob u jednání z řad veřejnosti. Vysvětlení celé věci je možno nalézt ve zprávě o činnosti soudu ze dne 14. 7. 1966, která obsahovala informace o činnosti soudu od 15. 2. 1965 do 30. 6. 1966, kde se v samém závěru konstatuje, že „kladem jest, že ZV-ROH doplnil členy MLS odbornou písařkou, která provádí zápisy při projednávání prŕípadů“. Z toho je patrné, že jednání jako taková konána byla, nicméně je neměl kdo protokolovat, a tak se zákon jednoduše nedodržoval a protokoly nevyhotovovaly. Ironicky lze poznamenat, že je jistě škoda, že proti ani jednomu rozhodnutí, kde nebyla prováděna protokolace, nebylo zároveň podáno odvolání, nebot' by bylo velmi zajímavé sledovat, na jakém podkladě by vlastně okresní soud o odvolání rozhodoval.

Na rozhodovací činnosti soudu se výrazně podílela i skutečnost, že soudci MLS byli v právu naprostými laiky. A tak zatímco ve skutkově jednoduchých věcech jako byly např́íklad prokázané prŕípady krádeží na pracovišti, kde byli pachatelé přistiženi prrímo při činu, nečinilo laickému senátu MLS problémy, jak rozhodnout a rozhodnutí př́esvědčivě zdůvodnit, jinak tomu bylo v př́padě trestných činů ve skutkově složitějších věcech. Např. dne 19. 3. 1965 vynesl senát MLS pod sp. zn. M 2/65 rozsudek, kterým uznal obžalovanou R. P. vinnou trestným činem ublížení na zdraví dle $\S 221$ odst. 1, odst. 3 tr. zákona a uložil jí veřejnou důtku, která bude vyvěšena po dobu 7 dnů na hlavní vrátnici závodu s velmi

43 První ve spisech založený protokol o jednání MLS je 7. 4. 1965, v předchozích spisech žádné protokoly o jednání MLS založeny nejsou. Vzhledem k celistvosti spisového materiálu a jeho výbornému nálezovému stavu je vyloučeno, že by př́ípadné protokoly ze spisu kdokoliv odstranil.

44 Zpráva o činnosti MLS při n. p. České loděnice Praha, závod Mělník ze dne 14. 12. 1963. 
lakonickým odůvodněním, že: „z výpovědi obžalované a svědků soud zjistil, že skutečně se dopustila shora jmenovaného trestného činu ublížení na zdraví ku škodě svého manžela J. P. dne 9. 12. 1964, tím, že při vzájemné roztržce hodila roztříštěnou lahví po manželovi tak nešt'astně, ${ }^{45}$ že mu způsobila středně těžké zranění na levé ruce. Soud přihlédnul i k okolnosti jednání J. S., které do značné míry ovlivnilo rozrušení R. P.“ Dle mého názoru takové zdůvodnění nemůže obstát, nebot' se vůbec nevyrovnalo se všemi okolnostmi př́ipadu a zejména pak s obhajobou samotné obžalované. Aniž bych chtěl zacházet do př́ilišných detailů případu, šlo ve zkratce o to, že oba manželé měli delší dobu trvající manželskou krizi, která vyvrcholila tím, že začali žít v jednom domě každý samostatně (R. P. v př́zemí, J. P. v podkroví). Dne 9. 12. 1964 při vzájemné hádce o užívání společné kůlny došlo k vzájemné fyzické potyčce mezi oběma manželi, kdy J. P. poškozenou několikrát udeřil do obličeje a ona ho několikrát kopla, přičemž J. P. násilně R. P. z kủlny vytlačil (zde se výpovědi obou manželů shodují). Poté měl, dle výpovědi obžalované, její manžel vzít do ruky koště a začít obžalovanou bít do hlavy a zad a ona na svoji obranu vzala do ruky láhev od vína, kterou když pozvedala, tak se rozbila a jí tak zbylo v ruce pouze hrdlo, které hodila po manželovi a ihned utekla k sousedce paní V. Verze manžela byla taková, že po konfliktu v kůlně manželka odcházela do svého bytu, on šel za ní a když se k manželce přiblížil, manželka vzala do ruky láhev od vína, která se jí v ruce rozbila a takto rozbitou láhví po něm hodila, přičemž mu způsobila poranění na ruce. Teprve poté manžel vzal do ruky koště a manželku s ním začal mlátit. Manželka posléze utekla k sousedce paní V. Klíčová v celém případu je podle mě výpověd' sousedky paní V., která uvedla, že v momentě, kdy uslyšela J. P., jak své manželce sprostě nadává, podívala se z okna a viděla, jak R. P. drží v ruce láhev od vína a nad její hlavou se vznáší koště. Poté co R. P. vběhla ke svědkyni domů, vyšla tato na chodbu, kde J. P. důrazně varovala před dalším napadáním manželky, přičemž si nevšimla, že by byl tento jakkoliv zraněn a že by mu tekla krev. J. P. pak z chodby odešel do svého bytu a poté přes chodbu odešel mimo dům, teprve po jeho odchodu si R. P. a paní V. všimly krvavých stop na chodbě, které musel zanechat J. P.

Jistě se shodneme, že okolnosti případu znali pouze jeho samotní aktéři, kteří měli nejrůznější motivace $\mathrm{k}$ tomu, proč odraz reality přizpůsobit svému zájmu, a tak tento př́ípad jistě nevyřešíme. Na druhou stranu bychom v tomto případě od soudního rozhodnutí očekávali, že soud se vyrovná se všemi okolnostmi případu, zejména přesvědčivě vysvětlí, proč považuje jednání obžalované za úmyslný trestný čin ${ }^{46}$ a hodnověrně se vyrovná s argumentem obžalované, že se žalovaného jednání dopustila v sebeobraně, nebot' na ní bylo útočeno ze strany poškozeného koštětem a již před tím ji poškozený napadl údery pěstí. Rozhodně bychom očekávali, že se soud vypořádá s výpovědí svědkyně V., která jednak uvedla, že viděla zvednuté koště již v okamžiku, kdy obžalovaná držela v ruce láhev od vína, tedy poškozený s ním musel manipulovat ještě před hozením láhve a v neposlední řadě se vyrovnat s tvrzením svědkyně, že bezprostředně po incidentu nezpozorovala u poškozeného žádné viditelné zranění.

45 Nejedná se o překlep, toto slovo bylo v rozsudku skutečně přeškrtnuto.

46 § 221 odst. 1 zákona č. 140/1961 Sb., trestní zákon, obsahoval skutkovou podstatu úmyslného ublížení na zdraví. 
Nic z toho se však nestalo, naopak po výslechu všech zúčastněných dal předseda senátu před vynesením rozsudku možnost vyjádřit se přítomným občanům k projednávané věci, kdy vystoupil spolupracovník poškozeného, který uvedl, že poškozeného zná velmi dobře a že je to „dobrý pracovník a dobrý manžel“. Zajímavá je rovněž protokolace závěrečné řeči obžalované: „Předseda udílí poslední závěrečné slovo R. P., která v závěru neprojevila lítost nad svým činem ani neprohlásila, že svého činu lituje“. Předně je třeba poznamenat, že obžalovaná od počátku tvrdila, že je nevinná a že jednala pouze v sebeobraně, tudíž se od ní ani nedalo čekat projevení lítosti nad takovým jednáním. Způsob takové protokolace dává již dopředu tušit, jak je senát před závěrečnou poradou rozpoložen. Co je tedy na tomto př́padě zřejmé, je fakt, že toliko laický senát nebyl vybaven potřebnou právní erudicí, aby se se skutkově a právně složitými případy vyrovnal. Argumentem pro takové rozhodnutí nemůže být ani zásada bezformálnosti řízení před MLS, nebot' ta se vztahovala na vlastní podobu projednávání kauzy před MLS, tj. na organizaci a řízení jednání, ale za žádných okolností „,nesměla nepř́iznivě ovlivňovat zjištění objektivní pravdy““ ${ }^{47}$ Na místě by však byla námitka, že takovéto kauzy ani dle zákona MLS nepř́slušely, nebot' dle $\S 24$ odst. 2 měly MLS projednávat věci řádně objasněné a že obžalovaná měla možnost se proti takovému rozhodnutí odvolat k okresnímu soudu. To je jistě pravdou, ale jak je vidět, i takové prŕpady MLS projednaly způsobem, který vzbuzuje mírně řečeno rozpaky. Navíc formulace posledně zmíněného paragrafu je dle mého názoru mimořádně nešt’astná, nebot' MLS staví do role pasivního verifikátora rozhodnutí učiněného jiným, navíc jednostranným subjektem (v tomto př́padě MO SBN, resp. prokurátora). Pokud jde o možnost odvolání, tak R. P. se v zákonné lhůtě neodvolala, nicméně dne 24. 10. 1965 podala předsedovi Okresního soudu v Mělníku žádost o obnovu trestního řízení. V této žádosti uvedla kromě své verze př́padu a pochybností o MLS zjištěném skutkovém stavu, též důvody, proč nepodala odvolání, když uvedla, že ,s rozsudkem MLS jsem nesouhlasila a chtěla jsem se odvolat. Toto odvolání mi nedoporučoval jak předseda MLS, tak i JUDr. K., naopak zastrašovali mne vyšším trestem.“ Zde by si mohl každý nezúčastněný člověk říci, že to oba zmínění aktéři mysleli v podstatě dobře a že trest, který obžalovanou postihl je v podstatě směšný a vzhledem k absenci zákazu reformace in peius při jejím odvolání je vlastně vítězstvím obžalované. Na druhou stranu je však třeba se i vcítit do pocitu člověka, který je skálopevně přesvědčen o své nevině a po 7 dní na vrátnici podniku, kde pracuje, je nucen si číst, jaký je násilník, a zároveň pracovat v kolektivu, který toto přesvědčení sdílí. Předsedovi Okresního soudu pak trvala odpověd' na žádost odsouzené necelé 2 měsíce, když jí prŕípisem ze dne 6. 12.1965 sdělil, že celé řízení bylo vedeno zákonně a zavinění odsouzené bylo prokázáno a že neshledal možnost podat mimořádný opravný prostředek, tj. v daném př́ipadě stížnost pro porušení zákona. Na konci tohoto přípisu si neodpustil poznámku o tom, že: „Je věcí posouzení celého prŕípadu, ovšem toto Vaše jednání mělo býti spíše posouzeno jako trestný čin větší společenské nebezpečnosti, a tudíž projednáno okresním soudem“, a dále nezapomněl odsouzené zdůraznit, že podle jeho názoru bylo odsouzené uloženo „spíše mírnější opatření s ohledem na vážný následek jejího jednání“. Nebýt těchto posledních poznámek byl by způsob takového vyřízení žádosti odsouzené po formální stránce v pořádku. Nicméně pokud předseda okresního soudu věc skutečně

47 Srov.: TOLAR, J. - P̌̌ENOSIL, G. - LAKATOŠ, M. Mistni lidové soudy. Praha: NČAV, 1965, s. 111. 
takto právně posoudil, postupoval ve věci protizákonně, nebot' rozhodnutím MLS byl porušen zákon tím, že rozhodoval věcně nepř́slušný orgán. ${ }^{48}$

I tak projednání věci předsedou okresního soudu v rozhodovací činnosti MLS byl posun k lepšímu. Zmiňovaný rozsudek nebyl v pořádku jen po stránce materiální, ale i formální, nebot' ve svém výroku vůbec neobsahoval skutkovou větu a po záhlaví rozsudku následoval vlastní výrok obsahující toliko označení obžalované a právní větu, za níž následovalo ustanovení o trestu. Vlastní skutek byl popsán až v odůvodnění rozsudku, a to ještě značně zjednodušeným způsobem, který v podstatě vylučoval subsumpci kvalifikované podstaty trestného činu ublížení na zdraví dle $\S 221$ ods. 1, odst. 3 tr. zák. A vzhledem k tomu, že to bylo první rozhodnutí MLS, které se oficiálně dostalo předsedovi okresního soudu do ruky, dovolím si vyslovit hypotézu, že tento se zasadil o nápravu, nebot' až na jednu dále zmíněnou výjimku, všechna další rozhodnutí MLS byla jak po stránce formální, tak materiální v souladu se zákonem.

Nebýt oné výjimky, kterou představovala věc vedená u MLS pod sp. zn. M 4/67, by bylo možno konstatovat, že rozhodovací činnost MLS se výrazně zlepšila a zprofesionalizovala. V této věci nejenže nebyl vyhotoven protokol o jednání, ale i samotný rozsudek ze dne 18. 7. 1967 je slušně řečeno lajdácký. Vzhledem k tomu, že se jednalo o jednoduchou a doznanou kauzu, nemá rozsudek problém s odůvodněním, nýbrž se záhlavím a výrokem samotným. V záhlaví se dočteme, že soud rozhodoval v senátě složeném z předsedy J. S. (uvedeno celé jméno) a soudců „Václava Dvo- a zapisovatelky M. T.“ (rovněž uvedeno celé jméno). Tedy z vyhotovení rozsudku při absenci protokolu o jednání není možné zjistit, kdo vlastně a zda při plném obsazení senátu o věci rozhodl. Rovněž právní kvalifikace skutku byla pofidérní, nebot' podle právní věty rozhodnutí provinilý spáchal „provinění proti socialistickému vlastnictví podle zákona 38/61 Sb, odstavec 1., o místních lidových soudech“. Pravdou je, že při znalosti zákona a z popisu skutku spočívajícího v rozbití skleněných tabulí hotelu lze snadno dovodit, že provinilec spáchal vlastně provinění proti majetku v socialistickém vlastnictví podle $§ 16$ odst. 1 zák. č. 38/61 Sb., ale na druhou stranu v takto vyhotoveném rozhodnutí nepůjde již o nepodstatná pochybení v rozhodnutí tak, jak je má na mysli § 34 odst. 4, nýbrž o zásadní porušení zákona, kdy vzhledem k absenci protokolu o jednání nelze ani určit, zda rozsudek byl takto i vyhlášen anebo chyba nastala až v souvislosti s jeho vyhotovením. I tak nelze argumentovat administrativní chybou, nebot' výše popsané deformované rozhodnutí podepsal sám předseda MLS, který byl zároveň předsedou senátu, který ve věci rozhodoval.

Bez zajímavosti jistě není ani fakt, že za celou dobu činnosti MLS bylo podáno pouze jedno odvolání, a to ve věci vedené pod sp. zn. M 7/65, kdy byl O. K. uznán vinným proviněním proti socialistickému soužití podle $\S 19$ odst. a, když dne 16. 4. 1965 při hádce se svojí bývalou manželkou tuto napadl pěstí a kopnutím, čímž jí způsobil zranění s pracovní neschopností 6 dnů, a byla mu uložena veřejná důtka, která byla uveřejněna na hlavní vrátnici závodu po dobu 7 dnů. Důkazní situaci komplikoval fakt, že k napadení mělo dojít bez přítomnosti třetích osob a oba aktéři ho líčili zcela odlišně a navíc i samotný provinilý byl prokazatelně poškozenou udeřen vařečkou. I když šlo o typově stejný případ jako ten pod sp. zn. M 2/65 a ve věci rozhodoval zcela totožný senát, je úroveň samotného

48 Srov. § 39 odst. 1 zákona č. 38/1961 Sb., o místních lidových soudech, ve spojení s $§ 34$ odst. 2 téhož zákona. 
rozhodnutí diametrálně odlišná. Rozsudek vynesený dne 30.9. 1965 má po formální stránce všechny náležitosti rozhodnutí, tj. nechybí mu skutková věta a rovněž v odůvodnění se pečlivě vypořádává se všemi argumenty obžaloby i obhajoby, včetně hodnocení důkazů ve vztahu k výpovědi jak provinilého a poškozené, tak k výpovědím několika svědků líćících vztah a vzájemné vztahy obou aktérů incidentu. A tak i Okresní soud v Mělníku usnesením ze dne 25. 10. 1965 sp. zn. Mo 7/65 zamítl odvolání O. K. jako bezdůvodné a v odůvodnění tohoto rozhodnutí se pochvalně vyjádřil o práci MLS směrem k provedení a hodnocení důkazů, s nímž se ztotožnil.

Neméně zajímavá je i samotná forma rozhodnutí MLS. ${ }^{49}$ Zatímco vůbec první projednávaný případ před MLS, a to provinění, končí dne 28. 11. 1962 zprošt’ujícím „rozsudkem jménem republiky“, ostatně jako všechny po něm následující rozhodnutí o provinění, první př́pad, kdy se u MLS projednával trestný čin, končí dne 22. 6. 1964 „,rozhodnutím jménem republiky“. Stejná situace následuje i dne 22. 6. 1964 rovněž při vynesení rozhodnutí MLS v trestní věci. Zajímavé je, že všechna zmiňovaná rozhodnutí učinily senáty složené takřka ze stejných členů (pouze jeden člen senátu byl jiný). V daném případě se nejedná nejspíš o administrativní chybu, nebot' v poučení tohoto rozhodnutí je výslovně uvedeno „proti tomuto rozsudku lze podat odvolání“. Identický senát jako v př́padě vydání dvou posledních rozhodnutí v trestních věcech vynáší 10. 7. 1964 rozsudek v prŕípadě provinění. Další rozhodnutí o trestném činu vynáší MLS dne 19. 3. 1965, a to již ve formě rozsudku, a tuto formu zachovává až do zániku MLS.

\section{Zánik MLS}

MLS byly od svého vzniku předmětem mnoha publikací, článků a pojednání, které se co do svého obsahu tokem času měnily tak, jak se měnila doba samotná. Na počátku své existence byly MLS stavěny na piedestal vývoje zlidověného soudnictví a význačný prvek vývoje socialistické společnosti na přechodu ke komunismu. V pozdější době, zhruba od roku 1965, se začaly na jejich činnost a koncepci vůbec objevovat kritické hlasy volající po jejich reformě nebo dokonce zrušení. ${ }^{50}$ Mimořádně kriticky se k MLS postavil Dr. Vojtěch Přichystal v článku nazvaném „Komu dědictví po místních lidových soudech?“ Ten mj. uvedl: „Pročítáme-li dnes, po časovém odstupu několika let, materiál, který byl podkladem nejen pro koncepci, ale namnoze přímo pro znění zákona č. 38/1961 Sb., o místních lidových soudech, sotva se můžeme ubránit tísnivému podivu nad tím, jak hluše a frázovitě vyznívá ve světle dalšího společenského vývoje, jehož jsme byli svědky, a ve světle potřeb a požadavků navazujících na tento vývoj, tehdejší, vysoce kladné hodnocení společenské situace a optimistická prognóza dalšího vývoje. “51 Dr. Přichystal pak ve svém článku následně shrnul koncepci MLS raženou jednak samotným zákonem a jednak usnesením

49 § 7 zákona č. 38/1961 Sb., o místních lidových soudech, stanovil, že MLS rozhoduje rozsudky nebo rozhodnutími, jež se vyhlašují jménem republiky a v zákoně jsou dále uváděna souhrnně jako rozhodnutí. Komentář k zákonu pak věc vysvětluje tak, že zákon o MLS ,nestanoví výslovně, že by v některých případech rozhodnutí MLS musilo (a v ostatních nesmělo) mít označení rozsudek. I ta rozhodnutí MLS, jimiž se meritorně rozhodne věc (např. provinilec je uznán vinným proviněním a uloží se mu určité opatření), mohou být (a v tom se projevuje zásada bezformálnosti rízení) označena jako „rozhodnutí“ a není třeba je označovat jako „rozsudek“ - viz Zákon o místních lidových soudech, komentár, s. 40-41.

50 Srov. např. Socialistické soudnictví, 1968, č. 5, str. 8-11.

51 PŘICHYSTAL, V. Komu dědictví po místních lidových soudech? Socialistická zákonnost, 1969, č. 5-6, S. 310 . 
ÚV KSČ nazvaném „K otázkám dalšího upevňování socialistické zákonnosti a zlidovění soudnictví“, aby ji zhodnotil závěrem, že: „Několik let činnosti místních lidových soudů však ukázalo, že pěkná slova nestačí k vytvoření tomu odpovídající skutečnosti a že ani opakovaně a důrazně pronášené prognózy nezaručují, že vývoj půjde žádoucím směrem.“ Dále konstatoval, že prŕíčin, proč si MLS nezískaly autoritu, postavení a důvěru, jak bylo od nich očekáváno, je více, ale pro jejich rozbor je málo spolehlivých podkladů a sotva by se mohlo dojít k nesporným závěrům. Navíc by byla jistě prospěšná i komparace s obdobnými instituty $\mathrm{v}$ jiných socialistických zemích. I když se podrobněji k př́íčinám zrušení MLS nevyjádřil, přeci jen heslovitě uvedl některé z nich, a to: úpadek aktivity občanů v MLS, neuspokojující výsledky MLS, přecenění sil a možností tohoto článku soudní soustavy, organizační nedostatky, nedokonalost právní úpravy, celková situace společnosti a v neposlední řadě i změna postoje $\mathrm{ROH}$, tj. masové společenské organizace, která měla hrát v činnosti MLS důležitou úlohu a jež se dle jeho názoru po loňském přehodnocení svého postavení a svých úkolů od činnosti MLS a péče o ně distancovala. Více však se ve zmiňovaném článku o důvodech zrušení MLS nedočteme. ${ }^{52}$

Nutno podotknout, že i ostatní právnická literatura z doby po zrušení MLS se omezuje spíše na následky tohoto kroku a řešení eventuálních problémů, které se zrušením MLS vzniknou, než aby důvody jejich zániku obšírněji vysvětlovala. Je pravdou, že od roku 1965 bylo zrušení MLS navrhováno a byly též uváděny důvody pro takový krok, např. důsledné nevybudování jejich systému, nicméně současně s tím byla též navrhována i jejich reforma, která by MLS zachovala. ${ }^{53}$ Kromě čistě věcného hlediska měla budoucnost MLS i ideologický aspekt. Byly to přece MLS, které byly prezentovány jako ,významný krok naznačující směr vývoje soudních orgánů od orgánů státu v orgány budoucí komunistické samosprávy“ v duchu tezí marxismu leninismu. Jejich zrušení z důvodu nefunkčnosti by pak muselo vyvolat společensky nežádoucí otázku perspektivy přechodu do fáze komunismu.

Do všech shora uvedených úvah o budoucnosti MLS vstoupil nástup normalizace v důsledku okupace Československa vojsky Varšavské smlouvy. Nově nastupující politická garnitura se ostře vymezila proti dosavadnímu vývoji. ${ }^{54}$ Usnesení předsednictva ÚV KSČ ze dne 18. 5. 1970 konstatovalo, že: „Některé falešné teorie o samovolnosti zániku kriminality a přání nevidět tento rub společenského vývoje oslabily komplexní boj s kriminalitou. Státní mechanismus i orgány lidové moci nejsou dostatečně soustř̌eděny na odstraňování negativních jevi̊ společnosti a některé instituty (myšleno i MLS, pozn. autora) předbíhaly dosaženou úroveň morálního i politického uvědomění společnosti. Není jistě náhodné, že růst kriminality se projevuje od počátku 60 . let, kdy začaly být prezentovány teorie o plném dosažení socialistické společnosti, o úplném překonání třídních antagonismů a nastolení všelidové společnosti. Tomu byla přizpůsobována i trestní teorie a praxe. “55

\footnotetext{
52 Srov. např. P̌̌ICHYSTAL, $c . d$., s. 310-315.

53 Srov. např. ČERNÝ, J. - NĚMEC, V. Socialistický pořádek především z hlediska práce národních výborů. Socialistická zákonnost, 1966, č. 4, s. 206.

54 Srov.: Poučení z krizového vývoje ve straně a společnosti po XIII. sjezdu KSČ. Praha: SPN, 1972, s. 64 a násl.

55 NA, fond 1261/0ú, KSČ, č. j. ÚV 02/01, svazek 127.
} 
Nejlépe se o bezprostředních důvodech zrušení MLS dozvídáme z důvodové zprávy k vládnímu návrhu zákona o přečinech č. 150/1969 Sb., který pasivně abrogoval zákon o MLS. ${ }^{56} \mathrm{~V}$ ní se mj. konstatuje, že „Události poslední doby vyvolaly nutnost přijmout zákonné opatření č. 99/1969 Sb., postihující též jednání narušující v menší míře veřejný pořádek (...). Zkušenosti získané při postihu provinění ukázaly, že v závažnějších případech opatření, která mohla být pachatelům uložena místním lidovým soudem (...) nebyla dostatečně účinná. Proto došlo k vydání zákona č. 58/1965 Sb., který umožnil soudní postih pachatelů opětovně se dopouštějících výtržnictví, násilnictví a př́živnictví. Takovou možnost je třeba zachovat i v budoucnosti. Navrhovaný zákon tedy zavádí jednotný soudní postih jednak provinění (...) jednak přestupků (...). Tím se vytváří jednotná linie směřující k upevnění občanské kázně a disciplíny v práci i ve společnosti.“57

Na základě shora uvedených skutečností je pak evidentní, že MLS nemohly dobu nastupující normalizace přežít. Hlavním důvodem však nebyly jejich faktické shora zmiňované nedostatky, ale jejich koncepce coby smíšených institucí státu a občanů podílejících se na výkonu soudnictví formou vlastní samosprávy, nota bene za situace, kdy vzhledem $\mathrm{k}$ náladě mezi občany nebylo zajištěno, že v př́ípadě projevů nesouhlasu s oficiální politikou budou tyto náležitě takovým soudem potrestány. Tento poslední aspekt zmiňuje i shora citované usnesení předsednictva ÚV KSČ ze dne 18. 5. 1970: „Namísto společenského odsouzení protiprávní činnosti docházelo v některých případech $\mathrm{k}$ jejímu schvalování nebo nadržování v kolektivech na pracovišti nebo na veřejnosti a tím k izolaci orgánů bojujících proti kriminalitě. "58

MLS byly zrušeny k 1. 1. 1970 v souvislosti s nabytím účinnosti zákona o přečinech č. 150/1969 Sb. Kauzy, které do této doby nestihly MLS projednat, byly rozděleny mezi národní výbory (přečiny) a soudy (trestné činy a majetkové spory). ${ }^{59}$

\section{Závěr}

Místní lidové soudy byly dobově a ideologicky determinovaný institut, který měl přenést některé funkce státních orgánů na společenské organizace v duchu proklamovaného přechodu od socialismu ke komunismu. Z počátku adorovaný institut se ve své praktické činnosti stále více potýkal s nekoncepčností své vlastní entity. Z mého pohledu MLS nejvýstižněji charakterizoval Dr. Otakar Osmančík jako ,experiment““ ${ }^{60}$ Nutno podotknout, že experiment značně nepřipravený a nedomyšlený. Zásadní chybou bylo začlenit MLS do soustavy soudů jako její základní článek a zároveň ponechat vznik MLS pouze na dobrovolné bázi, čímž došlo k zásadní diskriminaci delikventů tam, kde MLS nebyly vůbec ustanoveny. Rovněž kombinace státně-nestátní instituce, laického rozhodování, hyperplazie deliktů při jejich nedostatečné diferenciaci, vedla k tomu, že MLS v praktické činnosti ani zdaleka nenaplňovaly principy v té době ražené socialistické zákonnosti.

56 Srov. § 16 odst. 2 písm. a) zákona č. 150/1969 Sb., o přečinech.

57 Vládny návrh zákona, ktorým sa mení a doplňuje zákon č. 36/1964 Zb. o organizácii súdov a o vol’bách sudcov, tisk 18 .

$58 \quad$ NA, fond 1261/0ú, KSČ, č. j. ÚV 02/01, svazek 127.

59 Srov. $\$ 15$ zákona č. 150/1969 Sb., o přečinech, čl. IV zákona č. 158/1969 Sb., kterým se doplňují a mění občanský soudní rád, notářský řád a zákon o mezinárodním právu soukromém a procesním, a $§ 13$ zákona č. 149/1969 Sb., novela zákona o trestním řízení soudním.

60 OSMANČÍK, c. d., s. 196. 
Bezprostřední důvod zániku MLS je pak spojen se změnou politických poměrů v zemi v souvislosti s nastupující normalizací a je tedy do značné míry vynucený a nepřirozený. Bylo by jistě zajímavé sledovat, jak by se institut MLS vyvíjel, kdyby nedošlo k tak zásadní změně poměrů, nebot' kromě návrhů na jejich zrušení byly diskutovány i možnosti jejich reformy. 